\title{
Testicular Monophasic Choriocarcinoma
}

National Cancer Institute

\section{Source}

National Cancer Institute. Testicular Monophasic Choriocarcinoma. NCI Thesaurus. Code C39935.

A choriocarcinoma that arises from the testis and is characterized by the predominance of cytotrophoblastic and intermediate trophoblastic cells. Syncytiotrophoblastic cells are absent or not prominent. 